\title{
CRÔNICA DE MEIO DE RUA
}

Francisco Renato Lima ${ }^{1}$

Certa ocasião, caminhava por uma larga e vazia rua de terra de uma cidade do interior piauiense, quando, ao longe, avistei um menino franzino, brincando de bola na frente das modestas casas que compunham o painel arquitetônico do pitoresco local. No meio daquela tranquilidade, o pequeno peralta parecia feliz, mas, ainda assim, era possível captar uma bocado de tristeza e solidão em seu olhar. Caminhei em sua direção, nossos olhares se entrecruzaram e sem que trocássemos uma palavra, aquele gesto significou uma intimidade muito grande entre nós. Eu, um homem adulto, pra lá dos meus quarenta anos, meio cansado e desiludido com algumas coisas da vida; e ele, um menino, de aparentemente sete anos, com um futuro de esperanças e de sonhos que o aguardavam. Naquele instante, igualamo-nos em nome do fascínio que a bola nos provocava.

A passos curtos, tomei chegada. Vi, em seus olhos, uma aceitação e um convite ao jogo. Chutei a bola, ao que ele rebateu e ali começou, na cumplicidade do silêncio, quebrado apenas pelo toque da bola, a gritaria incontrolável nas batidas dos corações de dois moleques de rua, brincando de futebol. Como testemunhas de nosso encontro, tivemos apenas o sol ao cair da tarde, o revoar dos pássaros e o barulho das folhas das árvores.

Sem trocar nenhuma palavra, conversamos por olhares e toques de bola. Aqueles minutos, mais pareceram uma eternidade, compartilhada pela maturidade de um homem de meia idade e um menino no seu pleno alvorecer: o encontro de metamorfoses, portanto.

'Terminada a partida', ambos saímos vencedores. Eu, cheio de vida, segui meu caminho; ele, ao que senti, encontrou em mim, um parceiro, o 'pedaço' que faltava para completar sua brincadeira - que passou a ser 'nossa', por fim. E, para trás, ficou o rastro de um momento que, ao que me parece, chegou bem perto de um estágio de felicidade plena, entre dois garotos descalços em uma brincadeira de jogo de bola no meio de rua.

Nesse momento, de volta a minha realidade, na selva de pedra do capitalismo selvagem, o mundo dos adultos, que me aprisiona nesse arranha-céu, olho pelo espelho e vejo que, em tempos aligeirados, como os de hoje, aquela foi uma experiência, ainda que breve, muito significativa para nós dois. Demos, um ao outro, o que precisávamos para tornar aquele momento completo: eu, a oportunidade de reviver a lembrança da criança livre, que, na infância, jogou futebol de rua; ele, o companheiro para mais uma partida de futebol, uma aventura que só alcança sua ventura plena, se

\footnotetext{
1 Professor e pesquisador nas áreas de Educação e Linguagem, atuando no âmbito da Educação Básica e Ensino Superior. Mestre em Letras - Estudos da Linguagem (UFPI). E-mail: fcorenatolima@,hotmail.com
} 
vivida coletivamente. Mais do que uma partida de futebol, comungamos da companhia e do calor humano que a urgência do momento pedia.

Semelhante a uma tatuagem grafada no meu tecido epitelial, essa é uma memória que me atravessará, por um tempo desmedido. Agora, quando o expediente noturno impunha o seu fim, com a cabeça mergulhada no travesseiro, sobreleva na lembrança, aquele encontro: dois tempos de vida em uma mesma sintonia: a paixão pelo futebol. E, com o coração cheio de esperanças de, pelo menos, durante o descanso nos braços de Morfeu, poder reviver aquela felicidade sentida. 